\title{
ANALIZA WPŁYWU JAKOŚCI ROZPOZNANIA PODŁOŻA GRUNTOWEGO NA OCENĘ STANU GRANICZNEGO NOŚNOŚCI I UŻYTKOWALNOŚCI NA PRZYKŁADZIE WYBRANEGO OBIEKTU
}

\author{
Piotr Osiński ${ }^{\bowtie}$, Edyta Nowakowska, Katarzyna Jeleniewicz, Marek Dohojda, \\ Eugeniusz Koda
}

Wydział Budownictwa i Inżynierii Środowiska, Szkoła Główna Gospodarstwa Wiejskiego w Warszawie, Warszawa

\begin{abstract}
STRESZCZENIE
Celem artykułu jest ocena wpływu rozpoznania podłoża gruntowego na posadowienie konstrukcji. Podstawą do opracowania były dokumentacje archiwalne (pierwotna i wtórna), między którymi stwierdzono znaczne rozbieżności. Projekt posadowienia analizowanego obiektu wykonano według pierwotnej dokumentacji, w której nie uwzględniono występowania w podłożu gruntów organicznych. W celu określenia znaczenia rozpoznania podłoża gruntowego przy wyborze posadowienia dokonano weryfikacji stanów granicznych posadowienia w obu dokumentacjach. Największe różnice stwierdzono przy obliczonym osiadaniu, które wynikły z uwzględnienia wpływu ściśliwości gruntów organicznych.
\end{abstract}

Słowa kluczowe: posadowienie bezpośrednie, rozpoznanie warunków geotechnicznych, grunty organiczne, osiadanie

\section{WSTĘP}

W przypadku działania obciążenia o danej wielkości oraz kierunku w gruncie zachodzą zmiany stanu naprężenia i odkształcenia. Posadowiony fundament obiektu stopniowo obciążany konstrukcją obiektu powoduje $\mathrm{z}$ czasem przyrost naprężeń $\mathrm{w}$ podłożu oraz jego osiadanie (Dąbska i Gołębiewska, 2012). Zadaniem fundamentu jest bezpieczne przekazanie obciążeń od konstrukcji wraz z ciężarem własnym na podłoże gruntowe. Jednym z podstawowych warunków poprawnej współpracy fundamentu $\mathrm{z}$ podłożem jest spełnienie kryteriów stanów granicznych (Puła, 2011).

Projektowanie fundamentów bezpośrednich polega przede wszystkim na sprawdzeniu warunków stanów granicznych nośności i użytkowalności. Jeśli osiagnięta zostanie graniczna wartość naprężenia w poziomie posadowienia, wtedy nie będzie już możliwy dalszy wzrost obciążenia, a w konsekwencji powstanie w nim poślizg (Rybak, 2009). Takie zjawisko określa się jako stan graniczny nośności. Osiągnięcie granicznej wartości nadmiernego bądź nierównomiernego przemieszczenia konstrukcji spowodowanego osiadaniem podłoża jest nazywane stanem granicznym użytkowalności. Dokładne oraz właściwe wykonanie rozpoznania podłoża gruntowego jest podstawą do podjęcia decyzji o wykorzystaniu właściwego (poprawnego i ekonomicznego) $\mathrm{w}$ danych warunkach rozwiązania dotyczącego sposobu posadowienia budowli oraz jego konstrukcji (Godlewski i Łukasik, 2016; Dohojda, Wagrowska i Witkowska-Dobrev, 2017; Koda i Godlewski, 2018). Często dodatkowym czynnikiem powodującym pogorszenie warunków posadowienia jest niesprawne odwodnienie

${ }^{凶}$ piotr_osinski@interia.pl 
Osiński, P., Nowakowska, E., Jeleniewicz, K., Dohojda, M., Koda, E. (2018). Analiza wpływu jakości rozpoznania podłoża gruntowego na ocenę stanu granicznego nośności i użytkowalności na przykładzie wybranego obiektu. Acta Sci. Pol. Architectura, 17 (3), 47-55. doi: 10.22630/ASPA.2018.17.3.28

lub jego brak (Koda, Matusiewicz i Osiński, 2017). W niniejszym artykule przedstawiona została analiza potencjalnego wpływu błędnego rozpoznania podłoża gruntowego na pracę fundamentu. W tym celu wykonano obliczenia sprawdzające spełnienie warunków stanu granicznego nośności i użytkowalności, według wytycznych Eurokodu 7, posadowienia obiektu w przypadku, którego projekt fundamentu bezpośredniego został wykonany w przypadku błędnie rozpoznanego podłoża oraz podłoża powtórnie zweryfikowanego.

\section{MATERIAt I METODY}

Obszarem badań niniejszej pracy jest centrum handlowe mieszczące się w dużej aglomeracji miejskiej, na północy Polski. Kubatura dwupoziomowego budynku wynosi powyżej $400000 \mathrm{~m}^{3}$. Na potrzeby rozbudowy galerii handlowej przeprowadzono rozpoznanie warunków geologiczno-inżynierskich. Na podstawie informacji uzyskanej z 35 otworów badawczych o łącznym metrażu prawie $300 \mathrm{~m}$, do maksymalnej głębokości $12 \mathrm{~m}$ oraz 3 sondowań CPTU o łącznym metrażu 34 m, do głębokości maksymalnej 14 m, wyróżniono następujące warstwy geotechniczne:

- warstwa I - zagęszczone nasypy budowlane z zawartością piasku drobnego oraz kamieni,
- warstwa IIa - piaski drobne średnio zagęszczone $I_{D}=0,50$,

- warstwa IIb - piaski drobne zagęszczone $I_{D}=0,70$,

- warstwa IIc - pospółka w stanie zagęszczonym $I_{D}=0,70$,

- warstwa IIIa - gliny i gliny piaszczyste w stanie plastycznym $I_{L}=0,40$,

- warstwa IIIb - gliny i gliny piaszczyste w stanie plastycznym $I_{L}=0,30$,

- warstwa IIIc - gliny i gliny piaszczyste w stanie twardoplastyczym $I_{L}=0,20$.

Autorzy pierwotnej dokumentacji geologicznoinżynierskiej określili budowę geologiczną jako prosta, a warunki geotechniczne jako przeciętne. Grunty z warstw IIIa i IIIb zakwalifikowano jednak jako grunty słabonośne. Ponadto $w$ dokumentacji zasugerowano, uwzględniając planowane obciążenia oraz dopuszczalne odkształcenie podłoża, potrzebe wzmocnienia warstwy IIIc, mimo iż stan gruntu zakwalifikowany był jako twardoplastyczny. Reszte warstw geotechnicznych uznano za nośne. Przykładowy profil geotechniczny zaczerpniety $\mathrm{z}$ dokumentacji pierwotnej przedstawiony został na rysunku 1 . Poziom posadowienia zgodnie $\mathrm{z}$ projektem zaproponowany został na rzędnych $-5,25 \mathrm{~m}$ p.p.t.

Podczas trwania prac związanych $\mathrm{z}$ rozbudowa, na etapie wykonywania wykopu fundamentowego, na

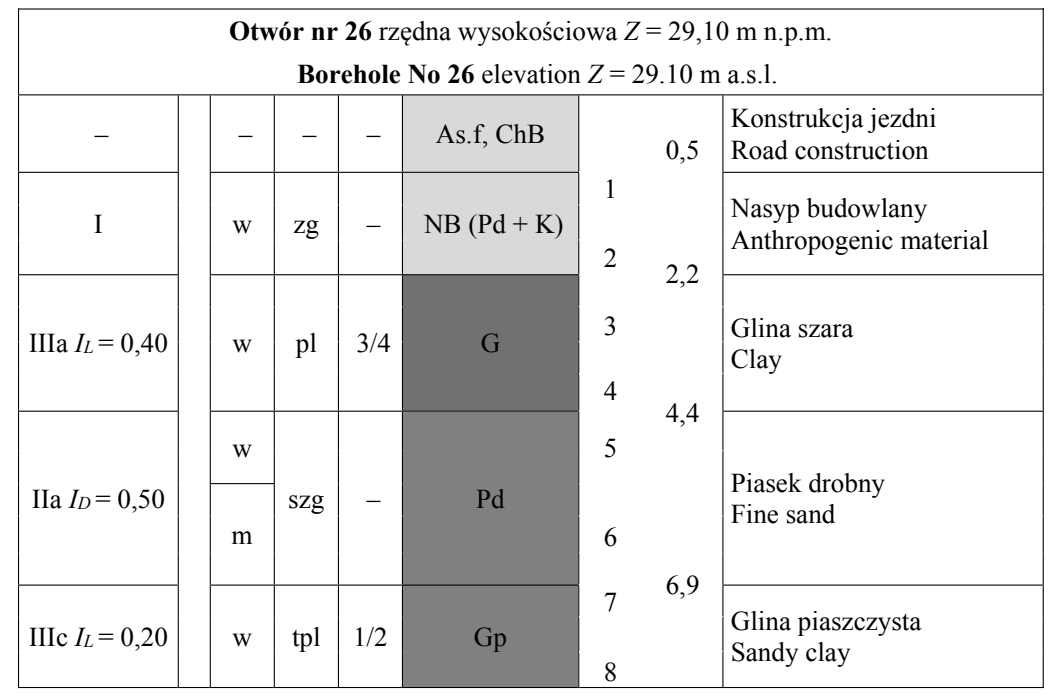

Rys. 1. Profil geotechniczny sporządzony według dokumentacji pierwotnej

Fig. 1. Geotechnical profile based on primary documentation 
Osiński, P., Nowakowska, E., Jeleniewicz, K., Dohojda, M., Koda, E. (2018). Analiza wpływu jakości rozpoznania podłoża gruntowego na ocenę stanu granicznego nośności i użytkowalności na przykładzie wybranego obiektu. Acta Sci. Pol. Architectura, 17 (3), 47-55. doi: 10.22630/ASPA.2018.17.3.28

zlecenie głównego wykonawcy przeprowadzone zostały dodatkowe badania $z$ poziomu posadowienia fundamentów, które zestawiono w sprawozdaniu z badań geotechnicznych. Związane to było z niezgodnością odkrytego materiału gruntowego podczas prac ziemnych w stosunku do informacji zawartych w pierwotnej dokumentacji geologiczno-inżynierskiej. Pomimo zaobserwowanych rozbieżności nie został stworzony projekt geotechniczny, który w zaistniałej sytuacji powinien zostać bezwzględnie wykonany. Na podstawie dodatkowo wykonanych badań przeprowadzonych już $\mathrm{z}$ poziomu dna wykopu fundamentowego, w podłożu wyodrębniono grunty rodzime i antropogeniczne, które znacznie różniły się litologią oraz parametrami geotechnicznymi w stosunku do tych określonych w dokumentacji geologiczno-inżynierskiej, na podstawie której opracowano projekt posadowienia obiektu.

Po przeprowadzonej ponownie analizie na podstawie 10 otworów do głębokości 8-15 m, uzupełnionych o sondowania CPTU do głębokości maksymalnej $10 \mathrm{~m}$, oraz sondowań DPL, wykonanych z poziomu pierwotnego poziomu posadowienia, warstwy geotechniczne podzielono ze względu na zbliżone wartości parametrów geotechnicznych:

- warstwa I - w jej skład wchodzą torfy i namuły,

- warstwa II - gliny zastoiskowe w stanie plastycznym $I_{L}=0,45$,

- warstwa IIIa - gliny piaszczyste morenowe w stanie plastycznym $I_{L}=0,40$,

- warstwa IIIb - gliny piaszczyste morenowe w stanie plastycznym $I_{L}=0,30$,

- warstwa IIIc - gliny piaszczyste morenowe w stanie twardoplastycznym $I_{L}=0,20$,

- warstwa IVa - piaski drobne będące w stanie średnio zagęszczonym $I_{D}=0,50$,

- warstwa $\mathrm{IVb}$ - piaski drobne i średnie będące w stanie zagęszczonym $I_{D}=0,70$.

$\mathrm{W}$ dokumentacji powykonawczej istnieje zapis, że ustalono warunki geologiczne w stopniu znacznie bardziej skomplikowanym niż wynika to $\mathrm{z}$ dokumentacji pierwotnej. Odnotowano występowanie gruntów organicznych (torfy, namuły oraz gytie) w północnozachodniej części badanego obszaru (rys. 2), sięgających do głębokości maksymalnie $5 \mathrm{~m}$ poniżej poziomu posadowienia, czego nie wykazano $\mathrm{w}$ dokumentacji z 2011 roku. Na pozostałym obszarze inwestycji na znacznej jego części ustalono, że występują tam osady holoceńskie zastoiskowe (pyły oraz gliny pylaste) w postaci plastycznej i miękkoplastycznej o miąższości $0,30-2,50 \mathrm{~m}$. Na podstawie danych uzyskanych podczas przeprowadzonych badań grunty $\mathrm{z}$ warstw geotechnicznych I, II i IIIa zakwalifikowano jako słabonośne. Na podstawie zebranych informacji zadecydowano o wymianie gruntów nienośnych na grunty niespoiste $\mathrm{w}$ stanie zagęszczonym $\left(I_{D}>0,65\right)$. Rzeczywiste warunki hydrogeologiczne były także znacznie bardziej złożone, a zwierciadło wód gruntowych lokalnie stabilizowało się $\mathrm{w}$ poziomie posadowienia.

$\mathrm{W}$ projekcie posadowienia, przygotowanego na podstawie pierwotnej dokumentacji geologiczno-inżynierskiej, która m.in. nie uwzględniała obecności gruntów organicznych, zaplanowano zastosowanie fundamentów bezpośrednich. W analizowanym przypadku były to stopy i ławy fundamentowe. Strefy ich występowania pokazano na rysunku 2 .

$\mathrm{W}$ pierwotnym projekcie posadowienia analizowanego obiektu budowlanego korzystano z metod obliczeniowych zawartych w normie PN-B-03020:1981, która w czasie wykonywania projektu była już nieaktualna. Polskie normy branżowe zastapił Eurokod 7, który stawia określone wymagania wobec obiektów budowlanych na terenie państw członkowskich Unii Europejskiej. Eurokod 7 (PN-EN-1997-1) jest tylko zbiorem zaleceń, więc nie posługiwanie się zawartymi w nim wytycznymi nie musi oznaczać popełnienia błędów projektowych (Wysokiński, Kotlicki i Godlewski, 2011). Podstawowe informacje o przemieszczeniach pionowych zachodzących na analizowanym obiekcie zweryfikowanych warunków posadowienia zawierała dokumentacja pomiarów geodezyjnych. Istotną obserwacją jest to, że część słupów umieszczono na stopach fundamentowych, które zostały posadowione w obszarze gruntów organicznych, wybranych już na etapie prac fundamentowych. Wykorzystując analizę dostępnej dokumentacji pierwotnej oraz wtórnej (sporządzonej po wykonaniu wykopu fundamentowego), dokonano doboru profili analitycznych otworów, które stanowiły podstawę do zweryfikowania poprawności projektu posadowienia. Obliczenia wykonano, wykorzystując pakiet programu GEO5 (Fine Ltd. 2016). Parametry gruntowe wykorzystane do obliczeń zestawiono $\mathrm{w}$ tabelach 1 i 2. 
Osiński, P., Nowakowska, E., Jeleniewicz, K., Dohojda, M., Koda, E. (2018). Analiza wpływu jakości rozpoznania podłoża gruntowego na ocenę stanu granicznego nośności i użytkowalności na przykładzie wybranego obiektu. Acta Sci. Pol. Architectura, 17 (3), 47-55. doi: 10.22630/ASPA.2018.17.3.28

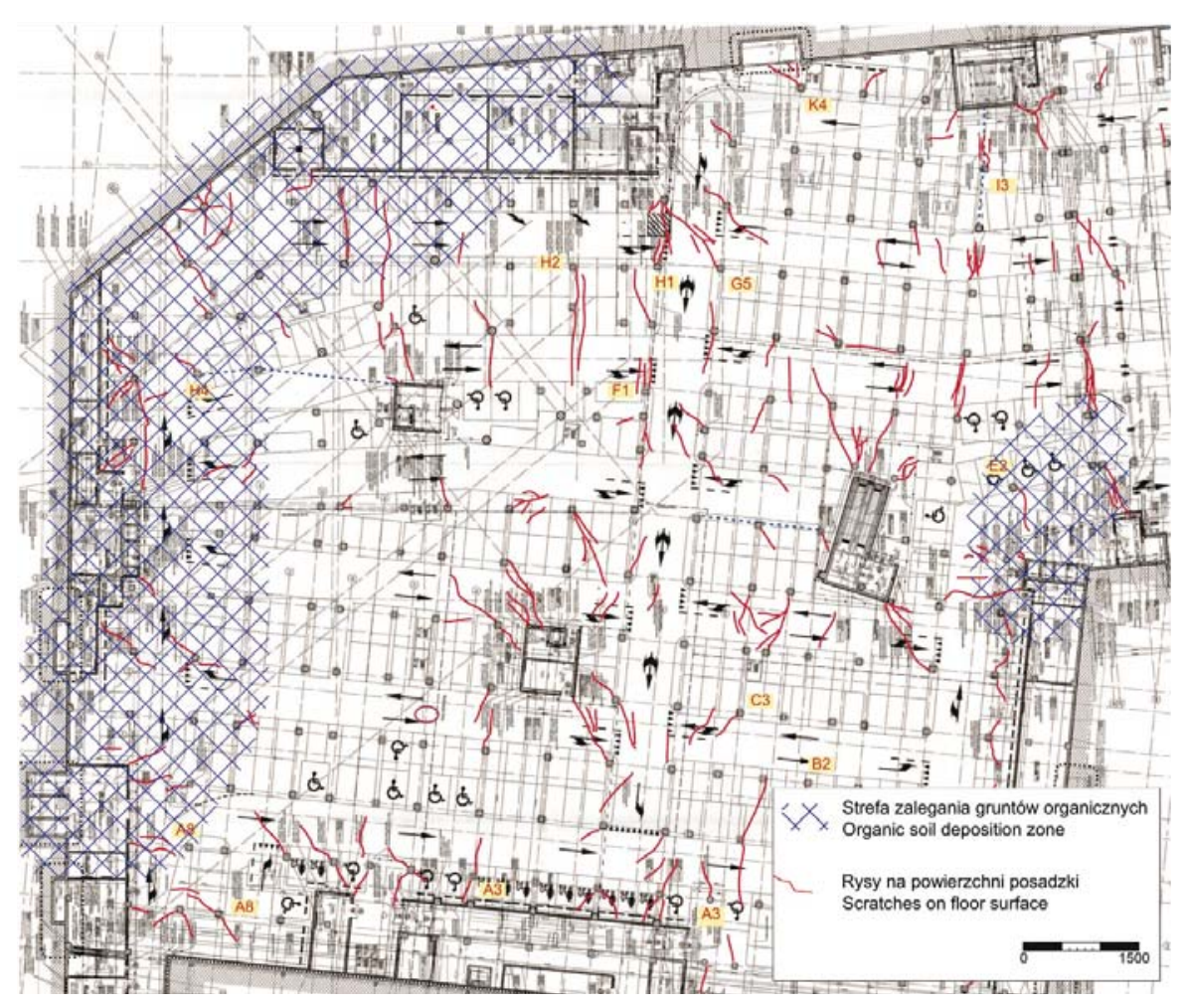

Rys. 2. Strefy występowania gruntów organicznych na terenie obiektu

Fig. 2. Organic soil deposition zones within the area of case study

Tabela 1. Parametry geotechniczne z pierwotnej dokumentacji geologiczno-inżynierskiej

Table 1. Geotechnical parameters from the primary geological documentation

\begin{tabular}{|c|c|c|c|c|c|c|c|c|}
\hline \multirow{2}{*}{$\begin{array}{l}\text { Warstwa geotechniczna } \\
\text { Geotechnical layer }\end{array}$} & \multirow{2}{*}{$\begin{array}{l}\text { Grunt } \\
\text { Soil }\end{array}$} & \multicolumn{2}{|c|}{$\begin{array}{l}\text { Stan gruntu } \\
\text { Soil state }\end{array}$} & \multicolumn{5}{|c|}{$\begin{array}{l}\text { Parametry gruntu } \\
\text { Soil parametres }\end{array}$} \\
\hline & & $\begin{array}{l}I_{D} \\
{[-]}\end{array}$ & $\begin{array}{l}I_{L} \\
{[-]}\end{array}$ & $\begin{array}{c}w_{n} \\
{[\%]}\end{array}$ & $\begin{array}{c}\rho \\
{\left[\mathrm{t} \cdot \mathrm{m}^{-3}\right]}\end{array}$ & $\begin{array}{c}c^{\prime} \\
{[\mathrm{kPa}]}\end{array}$ & $\begin{array}{l}\varphi \\
\left.{ }^{\circ}\right]\end{array}$ & $\begin{array}{c}M_{0} \\
{[\mathrm{MPa}]}\end{array}$ \\
\hline I & $\mathrm{NN}(\mathrm{Pd}+\mathrm{K})$ & $\mathrm{zg}$ & - & $\mathrm{w}$ & - & - & - & - \\
\hline II a & $\mathrm{Pd}, \mathrm{Ps}$ & 0,5 & - & $\begin{array}{l}\mathrm{w} 16 \\
\mathrm{~m} 24\end{array}$ & $\begin{array}{l}1,75 \\
1,90\end{array}$ & - & 30 & 32 \\
\hline II b & $\mathrm{Pd}$ & 0,7 & - & $\frac{\mathrm{w} 14}{\mathrm{~m} 22}$ & $\begin{array}{l}1,85 \\
2,00\end{array}$ & - & 32 & 60 \\
\hline II c & $\mathrm{Pd}$ & 0,7 & - & m 14 & 2,1 & - & 40 & 150 \\
\hline III a & $\mathrm{G}, \mathrm{Gp}$ & - & 0,4 & 18 & 2,08 & 11 & 14 & 9 \\
\hline III b & $\mathrm{G}, \mathrm{Gp}$ & - & 0,3 & 16 & 2,12 & 17 & 15 & 15 \\
\hline III c & $\mathrm{G}, \mathrm{Gp}$ & - & 0,2 & 14 & 2,16 & 27 & 17 & 20 \\
\hline
\end{tabular}


Osiński, P., Nowakowska, E., Jeleniewicz, K., Dohojda, M., Koda, E. (2018). Analiza wpływu jakości rozpoznania podłoża gruntowego na ocenę stanu granicznego nośności i użytkowalności na przykładzie wybranego obiektu. Acta Sci. Pol. Architectura, 17 (3), 47-55. doi: 10.22630/ASPA.2018.17.3.28

Kryterium doboru profili gruntowych było ich zlokalizowanie na obszarze, gdzie według dokumentacji wtórnej w poziomie posadowienia występowały grunty organiczne. Porównując obie dokumentacje, dopasowano trzy profile stóp fundamentowych $\mathrm{nr} 26$, 33 oraz 34. Ze względu na niemalże jednakowe warunki gruntowe stóp nr 33 i 34 (różniące się miąższościami poszczególnych warstw) profil przedstawiony został jedynie dla stopy $\mathrm{nr} 33$. Obliczenia pierwszego przypadku dotyczyły występujących (błędnie rozpoznanych) gruntów nośnych, a w drugim przypadku przeprowadzono obliczenia na podstawie profilów, w których poziomie posadowienia występowały m.in. grunty organiczne, jeszcze przed ich wymianą na grunty niespoiste spełniające warunki nośności. Tak wykonane obliczenia miały na celu ukazania potencjalnych różnic pracy konstrukcji w przypadku, gdy grunty słabe nie zostałyby wybrane z poziomu posadowienia, tak więc jest to sytuacja hipotetyczna. W rzeczywistości na potrzeby realizacji posadowie- nia grunty nienośne (organiczne i w stanie plastycznym) zostały wymienione do głębokości nawet $5 \mathrm{~m}$, a ich łączna kubatura wynosiła około $26000 \mathrm{~m}^{3}$.

Dopiero na tak przygotowanym podłożu wykonane zostały lawy i stopy fundamentowe. Do obliczeń warunków stanów granicznych błędnie rozpoznanego podłoża wykorzystano efektywne wartości parametrów geotechnicznych gruntu $\mathrm{z}$ pierwotnej dokumentacji geologiczno-inżynierskiej (do analizy w warunkach gruntowych prostych - tab. 1), do analizy stanów granicznych w zweryfikowanych warunkach gruntowych przyjęto zaś efektywne i całkowite wartości parametrów gruntowych w zależności od warunków panujących w poziomie posadowienia. Parametry zaczerpnięto ze sprawozdania wtórnego i pochodziły one $\mathrm{z}$ interpretacji wyników wykonanych sondowań CPTU (tab. 2). W przypadku parametrów gruntów organicznych zostały one dobrane według przeglądu literatury (Lechowicz i Szymański, 2002; Wiłun, 2005).

Tabela 2. Zestawienie parametrów geotechnicznych z dokumentacji wtórnej oraz przeglądu literatury (Lechowicz i Szymański, 2002; Wiłun, 2005)

Table 2. List of geotechnical parameters adopted for calculations based on secondary documentation and literature review (Lechowicz \& Szymański, 2002; Wiłun, 2005)

\begin{tabular}{|c|c|c|c|c|c|c|}
\hline \multirow{2}{*}{$\begin{array}{l}\text { Rodzaj gruntu } \\
\text { Soil type }\end{array}$} & \multirow{2}{*}{$\begin{array}{l}\text { Stan gruntu } \\
\text { Soil state }\end{array}$} & \multicolumn{5}{|c|}{$\begin{array}{l}\text { Parametry gruntu } \\
\text { Soil parameters }\end{array}$} \\
\hline & & $\begin{array}{c}\rho \\
{\left[\mathrm{t} \cdot \mathrm{m}^{-3}\right]}\end{array}$ & $\begin{array}{c}c_{u} \\
{[\mathrm{kPa}]}\end{array}$ & $\begin{array}{l}\varphi_{u} \\
{\left[{ }^{\circ}\right]}\end{array}$ & $\begin{array}{c}M_{0} \\
{[\mathrm{MPa}]}\end{array}$ & $\begin{array}{c}\varepsilon \\
{[-]}\end{array}$ \\
\hline $\begin{array}{l}\text { Grunt organiczny } \\
\text { Organic soil }\end{array}$ & - & 1,50 & 10 & 30,0 & 2,5 & 0,35 \\
\hline \multirow{2}{*}{$\begin{array}{l}\text { Glina piaszczysta } \\
\text { Sandy Clay }\end{array}$} & tpl & 2,16 & 27 & 17,0 & 20,0 & 0,35 \\
\hline & $\mathrm{pl} / \mathrm{mpl}$ & 2,12 & 17 & 15,0 & 15,0 & 0,35 \\
\hline \multirow{3}{*}{$\begin{array}{l}\text { Piasek drobny } \\
\text { Fine sand }\end{array}$} & $\ln$ & 1,65 & 0 & 28,0 & 15,0 & 0,30 \\
\hline & szg & 1,75 & 0 & 30,0 & 21,0 & 0,30 \\
\hline & szg & 2,20 & 0 & 35,5 & 43,0 & 0,28 \\
\hline $\begin{array}{l}\text { Glina } \\
\text { Clay }\end{array}$ & $\mathrm{mpl} / \mathrm{pl}$ & 2,08 & 10 & 14,0 & 9,0 & 0,40 \\
\hline $\begin{array}{l}\text { Torf } \\
\text { Peat }\end{array}$ & - & 1,10 & 5 & 30,0 & 0,6 & 0,35 \\
\hline
\end{tabular}




\section{WYNIKI I DYSKUSJA}

Wyniki sprawdzenia stanu granicznego nośności i użytkowalności uzyskano, korzystając z programu Geo5. Obliczenia przeprowadzone zostały przy zastosowaniu wytycznych Eurokod 7 dla wartości parametrów gruntu zestawionych w tabelach 1 i 2 w zależności od scenariusza obliczeń (odpowiednio dla przypadku błędnie rozpoznanego podłoża gruntowego i dla profili zweryfikowanych). W kalkulacjach zastosowane zostały współczynniki częściowe dedykowane do podejścia obliczeniowego DA2. Do obliczeń przyjęto sytuację obliczeniową stałą oraz uznano, że naprężenia od konstrukcji nie spowoduja istotnego przyrostu wartości ciśnienia wody w porach. Tak więc dla stóp, w których w poziomie posadowienia występowały grunty niespoiste, obliczenia przeprowadzone zostały dla warunków z odpływem, wykorzystując efektywne wartości parametrów mechanicznych, z kolei dla stóp posadowionych na warstwie gruntu spoistego zastosowano obliczenia w warunkach bez odpływu. Wyniki analiz stóp fundamentowych na tle zweryfikowanych profili geotechnicznych, przyjętych do obliczeń, pokazano na rysunkach 3 i 4 . Ponadto po analizie pierwotnego projektu posadowienia, przyjęto zaproponowane tam przez projektanta obciążenia tak, aby można było porównać uzyskane wyniki weryfikujące $\mathrm{z}$ wynikami zawartymi w projekcie pierwotnym. W przypadku, w którym stany graniczne sprawdzone zostały dla błędnie rozpoznanego podłoża, wyniki te pokrywały się (rozbieżności wynikały z różnic przyjętych współczynników częściowych zalecanych przez normę polską i Eurokod 7). Analizowane stopy, ich wymiary oraz obciążenia pozostały niezmienne względem projektu pierwotnego. Zdefiniowane stałe niekorzystne obciążenia pionowe wynosiły odpowiednio: dla stóp nr 26 i $34 V_{G}=6088 \mathrm{kN}$, a momenty zginające $M_{x, y}=$ $=150 \mathrm{kNm}$, zaś dla stopy $\mathrm{nr} 33 V_{G}=4017 \mathrm{kN}$, a moment zginający $M_{x, y}=100 \mathrm{kNm}$. Poziome obciążenia nie występowały, nie było też informacji na temat szybkości przyrostu naprężeń $\mathrm{w}$ trakcie wznoszenia obiektu. Wymiary stóp zostały zaprezentowane $\mathrm{w}$ tabeli 3. Z profili stóp nr 26 i 33 jednoznacznie wynika, iż grunty organiczne występują w początkowo zaprojektowanym poziomie posadowienia. Na podstawie przeprowadzonych obliczeń posadowienia wybrano najistotniejsze informacje, które zamieszczono w tabeli 3. Analizując dane z tabeli 3, można zauważyć, że $\mathrm{w}$ przypadku dokumentacji wtórnej (poprawne rozpoznanie podłoża) warunek stanu granicznego nośności pionowej analizowanych stóp nie jest spełniony. W przypadku stopy $\mathrm{nr} 26$ przekroczenia nie są znaczne, można tu jednak mówić o granicznym wykorzystaniu nośności. Z kolei dla stóp nr 33 i 34 przekroczenia przewyższają wartości $20 \%$.

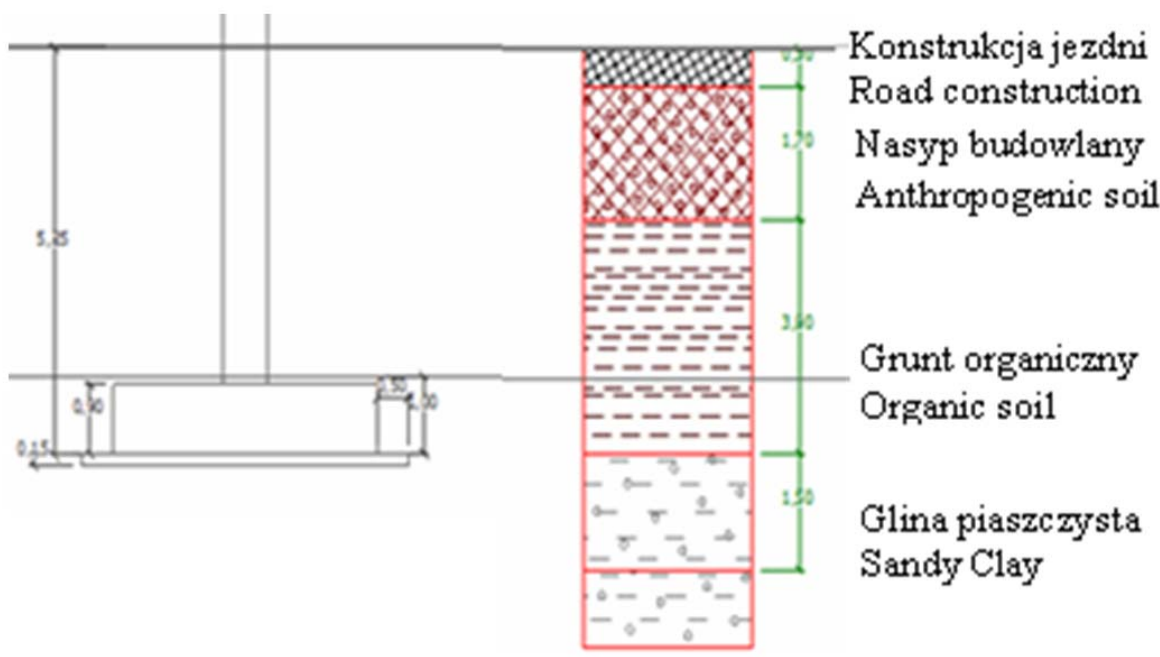

Rys. 3. Stopa fundamentowa $\mathrm{nr} 26$, na tle zweryfikowanego profilu geotechnicznego

Fig. 3. Pad foundation no 26, located within a verified geotechnical profile 


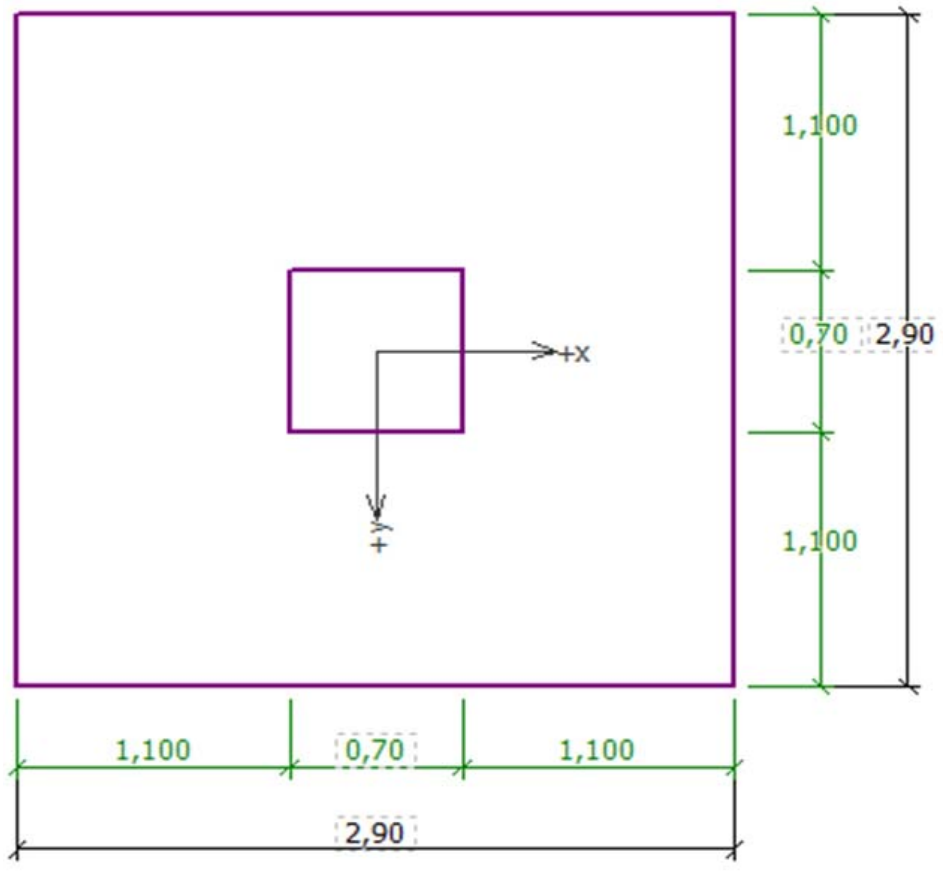

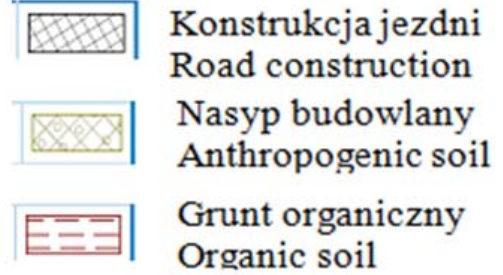

Piasek drobny

Fine sand

Torf

Peat

Piasek drobny

Fine sand

Torf

Peat

Glina

Clay

\section{Piasek średni}

Medium sand

Rys. 4. Wymiary stopy fundamentowej $\mathrm{nr}$ 33, na tle zweryfikowanego profilu geotechnicznego, poziom posadowienia na głębokości 4,85 m (w gruntach organicznych)

Fig. 4. Dimensions of pad foundation no 33, located within a verified geotechnical profile, foundation base at $4.85 \mathrm{~m}$ (within organic soil layer)

Tabela 3. Zestawienie najistotniejszych danych uzyskanych z obliczeń

Table 3. List of the most important data obtained from calculations

\begin{tabular}{|c|c|c|c|}
\hline $\begin{array}{l}\text { Stopa } \\
\text { Pad }\end{array}$ & $\begin{array}{l}\text { Parametr } \\
\text { Parameter }\end{array}$ & $\begin{array}{l}\text { Dokumentacja pierwotna } \\
\text { Primary documentation }\end{array}$ & $\begin{array}{c}\text { Dokumentacja wtórna } \\
\text { Scecondary documentation }\end{array}$ \\
\hline \multirow{4}{*}{$\begin{array}{l}\text { Stopa } 26 \\
\text { Pad } 26\end{array}$} & $\begin{array}{l}\text { Wymiary fundamentów }[\mathrm{m} \times \mathrm{m}] \\
\text { Dimensions }\end{array}$ & $4,0 \times 3,9$ & $4,0 \times 3,9$ \\
\hline & Nośność pionowa & spełniona $(99,4 \%)$ & przekroczona $(102,8 \%)$ \\
\hline & Bearing capacity & met & exceeded \\
\hline & $\begin{array}{l}\text { Osiadania }[\mathrm{mm}] \\
\text { Settlements }\end{array}$ & 38,6 & 42,7 \\
\hline \multirow{3}{*}{$\begin{array}{l}\text { Stopa } 33 \\
\text { Pad } 33\end{array}$} & $\begin{array}{l}\text { Wymiary fundamentów }[\mathrm{m} \times \mathrm{m}] \\
\text { Dimensions }\end{array}$ & $2,9 \times 2,9$ & $2,9 \times 2,9$ \\
\hline & $\begin{array}{l}\text { Nośność pionowa } \\
\text { Bearing capacity }\end{array}$ & $\begin{array}{c}\text { spełniona }(96,9 \%) \\
\text { met }\end{array}$ & $\begin{array}{l}\text { przekroczona }(120,0 \%) \\
\text { exceeded }\end{array}$ \\
\hline & $\begin{array}{l}\text { Osiadania }[\mathrm{mm}] \\
\text { Settlements }\end{array}$ & 20,1 & 269,4 \\
\hline \multirow{3}{*}{$\begin{array}{l}\text { Stopa } 34 \\
\text { Pad } 34\end{array}$} & $\begin{array}{l}\text { Wymiary fundamentów }[\mathrm{m} \times \mathrm{m}] \\
\text { Dimensions }\end{array}$ & $3,5 \times 3,4$ & $3,5 \times 3,4$ \\
\hline & $\begin{array}{l}\text { Nośność pionowa } \\
\text { Bearing capacity }\end{array}$ & $\begin{array}{c}\text { spełniona }(99,6 \%) \\
\text { met }\end{array}$ & $\begin{array}{c}\text { przekroczona }(120,8 \%) \\
\text { exceeded }\end{array}$ \\
\hline & $\begin{array}{l}\text { Osiadania }[\mathrm{mm}] \\
\text { Settlements }\end{array}$ & 27,5 & 368,8 \\
\hline
\end{tabular}


Powodem tych rozbieżności są odmienne od pierwotnie udokumentowanych warunki gruntowe oraz zweryfikowane parametry geotechniczne przyjęte do obliczeń. Metody obliczeniowe zastosowane do analizy obu przypadków pozostały ujednolicone. Wykonano je metodą stanów granicznych połączoną z zastosowaniem współczynników częściowych zalecanych przez Eurokod 7 zgodnie z załącznikiem krajowym. Obliczenia stanu granicznego użytkowalności wskazują, że wartości spodziewanych osiadań znacznie odbiegaja od tych wyznaczonych według pierwotnej dokumentacji. Przekroczenia są bardzo duże (nawet 17-krotne), co jest wynikiem występowania nienośnych gruntów organicznych w poziomie posadowienia, o bardzo małych wartościach parametrów wytrzymałościowych i odkształceniowych (tab. 2). Z uwagi na to, że stopy nr 33 i 34 posadowione sa w bardzo zbliżonym profilu gruntowym, zaprezentowany został jedynie profil stopy nr 33 (rys. 4).

Obserwacje rys posadzkowych w budynku, w rejonie stóp fundamentowych nr 33 i 34, niejako potwierdzają te wyniki i mogą świadczyć o nierównomiernym osiadaniu budowli. Mimo iż po weryfikacji warunków gruntowo-wodnych wymieniono grunt, to zjawisko występowania rys na posadzkach może świadczyć o niedostatecznej głębokości ich wymiany podczas wykonywania prac fundamentowych lub niedostatecznym zagęszczeniu wbudowanego gruntu. W lokalizacjach najtrudniejszych warunków geotechnicznych głębokość wymiany gruntów sięgała $5 \mathrm{~m}$, a łączna kubatura wymienionego gruntu wynosiła około $26000 \mathrm{~m}^{3}$. Obliczenia mają charakter czysto teoretyczny i mają za zadanie uzmysłowić, jakie konsekwencje może mieć błędne rozpoznanie podłoża gruntowego na pracę fundamentów.

\section{PODSUMOWANIE}

W artykule wykazano, w jaki sposób nieuwzględnienie w dokumentacji pierwotnej gruntów organicznych mogło mieć poważne konsekwencje na pracę analizowanego obiektu. Wynika to $\mathrm{z}$ tego, iż grunty rozpoznane w omawianej inwestycji charakteryzują się dużym zróżnicowaniem $\mathrm{w}$ odniesieniu do zachowania się pod działaniem obciążenia. Posadowienie na gruntach organicznych powoduje znaczne problemy związane z wystapieniem dużych poziomych oraz pionowych odkształceń podłoża $\mathrm{w}$ trakcie i po zakończeniu procesu budowy obiektu. Zaprezentowane wyniki wskazują na znaczne rozbieżności w przypadku obu scenariuszy obliczeniowych do wartości ich osiadań. Takie podejście jest skutkiem błędnego rozpoznania podłoża i może być powodem pojawienia się trudności $\mathrm{z}$ utrzymaniem stateczności budowli w sytuacji niedostatecznej głębokości wymiany gruntu. Podkreślić również należy to, iż w takich przypadkach sposób posadowienia powinien skłaniać się ku rozwiązaniom fundamentów głębokich (pośrednich) bądź też właściwej wymiany gruntu w podłożu, co ostatecznie zostało zrealizowane po odkryciu gruntów organicznych w pierwotnie projektowanym poziomie posadowienia. Przeanalizowany przypadek potwierdza fundamentalne znaczenie rozpoznanie podłoża gruntowego na potrzeby wykonania bezpiecznego projektu posadowienia. Zwraca on uwagę na istotę podjęcia właściwej decyzji w momencie stwierdzenia tak rażących błędów w dokumentacji geologiczno-inżynierskiej, jakie zostały opisane w niniejszym artykule.

\section{PIŚMIENNICTWO}

Dąbska, A. i Gołębiewska, A. (2012). Podstawy geotechniki. Zadanie wedtug Eurokodu 7. Warszawa: Oficyna Wydawnicza Politechniki Warszawskiej.

Dohojda, M., Wągrowska, M. i Witkowska-Dobrev, J. (2017). Wielostanowiskowe garaże podziemne - przykłady rozwiązań konstrukcyjnych. Acta Scientiarum Polonorum, Architectura, 16 (4), 27-35.

Fine Ltd. (2016). GEO5. Podręcznik użytkownika. Praga: Fine Ltd.

Godlewski, T. i Łukasik, S. (2016). Diagnostyka podłoża budowlanego według Eurokodu 7. Wybrane zagadnienia. W Rzeczoznawstwo budowlane: Diagnostyka i wzmacnianie obiektów budowlanych (strony 186-218). Kielce: Wydawnictwo Politechniki Świętokrzyskiej.

Koda, E. i Godlewski, T. (2018). Zasady wykonywania ekspertyz geotechnicznych z uwzględnieniem budynków w zabudowie miejskiej. W XV Konferencja NaukowoTechniczna , Warsztat Pracy Rzeczoznawcy Budowlanego", Kielce-Cedzyna (strony 81-108).

Koda, E., Matusiewicz, W. i Osiński, P. (2017). Niesprawność systemów odwadniających w obiektach budowlanych. W XXVIII Konferencja Naukowo-Techniczna „Awarie Budowlane”, Międzyzdroje (strony 411-422). 
Osiński, P., Nowakowska, E., Jeleniewicz, K., Dohojda, M., Koda, E. (2018). Analiza wpływu jakości rozpoznania podłoża gruntowego na ocenę stanu granicznego nośności i użytkowalności na przykładzie wybranego obiektu. Acta Sci. Pol. Architectura, 17 (3), 47-55. doi: 10.22630/ASPA.2018.17.3.28

Lechowicz, Z. i Szymański, A. (2012). Odksztatcenia i stateczność nasypów na gruntach organicznych. Cz. 1 i 2. Warszawa: Wydawnictwo SGGW.

PN-EN 1997-1. Eurokod 7: Projektowanie geotechniczne. Część 1: Zasady ogólne.

PN-B-03020:1981. Grunty budowlane. Posadowienie bezpośrednie budowli.

Puła, O. (2011). Projektowanie fundamentów bezpośrednich wedtug Eurokodu 7. Wrocław: Dolnośląskie Wydawnictwo Edukacyjne.
Rybak, Cz. (2001). Fundamentowanie. Projektowanie posadowień. Wyd. 6. Wrocław: Dolnośląskie Wydawnictwo Edukacyjne.

Wiłun, Z. (2005). Zarys Geotechniki. Warszawa: Wydawnictwa Komunikacji i Łączności.

Wysokiński, L., Kotlicki, W. i Godlewski, T. (2011). Projektowanie geotechniczne wedlug Eurokodu 7. Warszawa: Instytut Techniki Budowlanej.

\title{
INFLUENCE OF THE SITE INVESTIGATION QUALITY ON ULTIMATE AND SERVICEABILITY LIMIT STATES ANALYSES BASED ON A CASE STUDY
}

\begin{abstract}
The aim of the study is to assess the impact of the site investigation on the foundation design. The basis for the research was the archive documentation (primary and secondary), between which researchers found significant discrepancies. The foundation design of the analysed structure was based on improperly prepared primary documentation which did not take into account the presence of organic soils within the subsoil. To determine the significance of ground investigation, the verification of limit states for analyzed structure was performed for data obtained from both documentations. The most significant findings are the computed dimensions of footings, subsidence, horizontal and vertical bearing capacity. The most significant differences are visible for computed settlements, which results from taking into account high compressibility of the organic soil.
\end{abstract}

Key words: spread foundation, site investigation, organic soil, limit states, settlements 